\title{
YIELD OF CHICKPEAS SOWN AT DIFFERENT TIMES ${ }^{1}$
}

\author{
RAMON IVO SOARES AVELAR ${ }^{2 *}$, CÂNDIDO ALVES DA COSTA ${ }^{2}$, FERNANDO DA SILVA ROCHA $^{2}$, NELSON \\ LICÍNIO CAMPOS DE OLIVEIRA ${ }^{3}$, WARLEY MARCOS NASCIMENTO ${ }^{4}$
}

\begin{abstract}
In Brazil, studies on chickpeas (Cicer arietinum L.) have demonstrated the high productive potential of this crop, especially in the Cerrado areas of Cristalina, GO, and Brasília, DF. Due to dry winter climatic conditions, the North of Minas Gerais may be very suitable for the production of this crop. However, more information on chickpea sowing dates is needed. Therefore, the objective of the present study was to evaluate different chickpea sowing times in two municipalities of Minas Gerais State in Brazil: Montes Claros and Januária. The experiment was carried out in a randomized block design, comprising three sowing dates (12 May, 23 June, and 22 July, 2015), and seven replications. The cultivar used was BRS Aleppo, and the chickpeas were harvested 121 days after sowing. The variables evaluated included plant height, productivity, number of pods with one grain, and number of pods with two grains. The data were submitted to analysis of variance, and joint analysis of the experiments was performed. The highest yields were obtained when chickpeas were sown in May in Montes Claros, with a yield of $5.3 \mathrm{t} \mathrm{ha}^{-1}$. In Januária, chickpeas sown in May and June produced yields greater than $3.0 \mathrm{t} \mathrm{ha}^{-1}$. The plants sown in July, considered late for planting, were harvested during the rainy season, which compromised the quality and yield of the grains. In addition, maximum temperatures above $30^{\circ} \mathrm{C}$ were recorded from September onwards in both locations, which also resulted in a reduction in the number of grains per plant. Thus, this sowing season is not recommended in the studied region.
\end{abstract}

Keywords: Cicer arietinum. Leguminosae. Winter crops. BRS Aleppo.

\section{PRODUTIVIDADE DO GRÃO-DE-BICO EM DIFERENTES ÉPOCAS DE SEMEADURA}

\begin{abstract}
RESUMO - Trabalhos realizados com a cultura do grão-de-bico (Cicer arietinum L.) no Brasil evidenciam elevado potencial produtivo desta espécie, especialmente nas áreas de cerrado de Cristalina, GO e Brasília, DF. O Norte de Minas Gerais possui potencial produtivo por apresentar condições de inverno seco. Entretanto, mais informações sobre épocas de semeadura do grão-de-bico precisam ser levantadas. Dessa forma, objetivou-se avaliar a melhor época de semeadura do grão-de-bico nos municípios de Montes Claros e Januária, MG. $\mathrm{O}$ experimento foi realizado em blocos completos ao acaso, compreendendo três épocas de semeadura (12/Maio, 23/Junho, 22/Julho) e sete repetições. A cultivar utilizada foi BRS Aleppo e a colheita realizada aos 121 dias após a semeadura. Foram variáveis analisadas foram: altura de plantas, produtividade, número de vagens com um grão e número de vagens com dois grãos. Os dados foram submetidos à análise de variância sendo realizada a análise conjunta dos experimentos. Maiores produtividades foram obtidas em Montes Claros na semeadura realizada no mês de maio com produtividade de $5,3 \mathrm{t} \mathrm{ha}^{-1}$, e em Januária nas semeaduras de Maio e Junho, com produtividades superiores a 3,0 $\mathrm{tha}^{-1}$. Por ser tardia, verificou-se que para a semeadura no mês de Julho ocorreu chuvas no período de colheita, comprometendo a qualidade e rendimento dos grãos. Além disso, foram registradas temperaturas máximas superiores a $30^{\circ} \mathrm{C}$ a partir do mês de Setembro nas duas localidades, o que resultou também na redução do número de grãos por planta. Assim, essa época de semeadura não é recomendada nos municípios estudados.
\end{abstract}

Palavras-chave: Cicer arietinum. Leguminosae. Cultivo de inverno. BRS Aleppo.

\footnotetext{
*Corresponding author

${ }^{1}$ Received for publication in 03/31/2017; accepted in 04/23/2018.

Paper extracted from the master dissertation of the first author.

${ }^{2}$ Institute of Agrarian Sciences, Universidade Federal de Minas Gerais, Montes Claros, MG, Brazil; ramonavelar.agronomia@yahoo.com ORCID: 0000-0003-1398-2245, candido-costa@ica.ufmg.br - ORCID: 0000-0002-1859-1422, rochafs@ufmg.br - ORCID: 0000-00022506-3441.

${ }^{3}$ Instituto Federal do Norte de Minas Gerais, Januária, MG, Brazil; nelson.oliveira@ifnmg.edu.br - ORCID: 0000-0002-2198-5713.

${ }^{4}$ National Center for Vegetable Crops Research, Embrapa Hortaliças, Brasília, DF, Brazil; warley.nascimento@embrapa.br - ORCID: 0000 $-0002-6235-0917$.
} 


\section{INTRODUCTION}

The chickpea (Cicer arietinum L.) is an important legume, known for its nutritional characteristics. The chickpea plays a key role in feeding millions of people around the world, especially in India, which is the largest producer and consumer (JUKANTI et al., 2012; RAO et al., 2010). It is the second most cultivated legume in the world, with a great variety of genotypes divided into two groups according to the size of the seeds, including the Kabuli (large) and Desi (small) groups (VARSHNEY et al., 2013a).

Low productivity of chickpeas has been observed in many countries, with averages of less than $1.2 \mathrm{t} \mathrm{ha}^{-1}$ (FAO, 2018), due mainly to water stress conditions, salinity, and heat (VARSHNEY et al., 2013b; KHAMSSI et al., 2011; MAFAKHERI et al., 2010; GUNES et al., 2008). Most of the crops in the world are farmed with limited technology (ABATE; ORR, 2012), and in rain-fed land, taking advantage of the residual water from the rainy season (ALI, 2017). However, some countries, including Israel (6.04 t ha ${ }^{-1}$ in 2012), China (5.2 $\mathrm{t} \mathrm{ha}^{-1}$ in 2015), and Moldova (3.9 $\mathrm{t} \mathrm{ha}^{-1}$ in 2016) have achieved high chickpea yields.

The cultivation of chickpeas is still not widespread in Brazil, and the production is insufficient to serve the consumer market, which depends on imports. Current imports are approximately 8,000 tons/year, which cost the country nearly $\$ 9$ million (NASCIMENTO et al., 2016).

The cultivation of chickpeas is recommended in the spring/summer in milder climates, or in winter in tropical climates (NASCIMENTO et al., 2016). Although considered a cold weather legume, the chickpea adapts very well to tropical regions, where it develops well and has good productivity. In addition, chickpeas are tolerant to water deficits (BRAGA; VIEIRA; VIEIRA, 1997).

In the reproductive period of chickpeas, mild temperatures and dry conditions favor the culture, since these conditions help avoid floral abortion and result in a better formation of pods. In general, the highest yields are obtained at altitudes above $600 \mathrm{~m}$, with night temperatures below $15{ }^{\circ} \mathrm{C}$ (NASCIMENTO et al., 2016).

Studies show that the Northern Region of Minas Gerais has a high potential for cultivation of chickpeas. Hoskem et al. (2017) evaluated the production and quality of seeds of chickpeas(Cicero cultivar) in two locations in the city of Montes Claros - MG, and found that the best time for sowing is in the month of June, with yields of $3.2 \mathrm{t} \mathrm{ha}^{-1}$ and $3.9 \mathrm{t} \mathrm{ha}^{-1}$, respectively. A study by Vieira, Resende and Castro (1999), in Janaúba, MG, using the Leopoldina and IAC Moroco cultivars reported productivity greater than $3 \mathrm{t} \mathrm{ha}^{-1}$.

Recently, Embrapa Hortaliças launched the
BRS Aleppo cultivar, which is more productive, and tolerant to diseases caused by fungi. This cultivar was introduced in Brazil in 2010, and participated in several trials in the Federal District (DF) and Goiás (GO) before its release in the year 2013, including in irrigated areas of commercial production (NASCIMENTO et al., 2014). The results indicated that the Aleppo cultivar had productive performances than the Cicero cultivar. The yield was on average $3.0 \mathrm{t} \mathrm{ha}^{-1}$, which is considered high, when compared to the Cicero cultivar, which had an average yield of $0.94 \mathrm{t} \mathrm{ha}^{-1}$ (ARTIAGA et al., 2015).

However, further studies are needed to determine the best time for sowing chickpeas for maximum efficiency and expansion of production areas. Therefore, this study aimed to evaluate the best time to sow chickpeas in two municipalities in the North of Minas Gerais.

\section{MATERIAL AND METHODS}

The experiments were performed between May and November of 2015. Studies were conducted in the municipalities of Montes Claros - MG, Brazil ( $16^{\circ} 40^{\prime} 56^{\prime \prime} \mathrm{S}, 43^{\circ} 50^{\prime} 24^{\prime \prime} \mathrm{W}$, at an altitude of $\left.646 \mathrm{~m}\right)$ in the experimental area of the Agricultural Sciences Institute of UFMG, and in Januária - MG (15 $26^{\prime}$ $47^{\prime \prime} \mathrm{S}, 44^{\circ} 22^{\prime} 05^{\prime \prime} \mathrm{W}$ and a height of $474 \mathrm{~m}$ ), at the Federal Institute of Technology North of Minas Gerais - IFNMG. The climate classification of municipalities is KöppenAw, located in microregions in the North of Minas Gerais.

The chemical and physical characteristics of soils of the experimental areas in Montes Claros MG and Januária - MG are presented in Table 1.

Data on precipitation, maximum and minimum daily temperatures, collected by the National Institute of Meteorology (BRASIL, 2016) during the experiments, at the two sites, are presented in Table 2.

The statistical design used was randomized blocks, and chickpeas were sown at three different times (May $12^{\text {th }}$, June $21^{\text {st }}$, and July $22^{\text {nd }}, 2015$ ), and in two locations (Montes Claros - MG and Januária $\mathrm{MG})$, with seven replicates.

Each farmed plot of chickpeas (BRS Aleppo) was composed of four rows of five meters in length, spaced $0.50 \mathrm{~m}$ apart. Before planting, the seeds were treated with fungicide and insecticide phenylurea (systemic, contact and ingestion of groups: neonicotinoid and methylcarbamate of oxime), respectively. Ten plants were seeded per meter, which corresponded to a density of 200,000 plants ha ${ }^{-1}$. The experimental plots consisted of $1.0 \mathrm{~m}^{2}$ in the two central rows, and the rest was considered as a perimeter. The BRS Aleppo plants have a semi-erect profile, an average height of $66 \mathrm{~cm}$, and three to four branches per plant. The cycle is around 120 days 
after emergence (DAE), and the seeds are 8 to 9.5 $\mathrm{mm}$ of diameter (NASCIMENTO et al., 2014).

The fertilization and irrigation followed the recommendations of Nascimento et al. (2016), considering Cerrado soils of low fertility. Fertilizing consisted of $400 \mathrm{~kg} \mathrm{ha}^{-1}$ of the formula 4-30-16 in crops and $60 \mathrm{~kg} \mathrm{ha}^{-1}$ of nitrogen $(\mathrm{N})$ in coverage, between 40 and 50 days after sowing, prior to the beginning of flowering. Irrigations were carried out using micro-aspersion.

Table 1. Chemical and physical characterization of soils of the experimental areas in the municipalities of Montes Claros and Januária, Minas Gerais.

\begin{tabular}{|c|c|c|c|c|c|c|c|c|c|c|}
\hline \multicolumn{11}{|c|}{ Chemical Characterization } \\
\hline \multirow{2}{*}{ Local } & \multirow{2}{*}{$\mathrm{pH}$} & $\mathrm{P}$ & $\mathrm{K}$ & $\mathrm{Al}$ & $\mathrm{H}+\mathrm{Al}$ & $\mathrm{Ca}$ & $\mathrm{Mg}$ & $\mathrm{OM}$ & rem-P & $\mathrm{V}$ \\
\hline & & \multicolumn{2}{|c|}{$\left(\mathrm{mg} \mathrm{dm}^{-3}\right)$} & \multicolumn{4}{|c|}{$\left(\mathrm{cmolc} \mathrm{dm}^{-3}\right)$} & $\left(\right.$ dag kg $\left.{ }^{-1}\right)$ & $\left(\mathrm{mgL}^{-1}\right)$ & $(\%)$ \\
\hline Januária & 7.1 & 255 & 134 & 0.0 & 1.08 & 2.8 & 1.2 & 3.39 & 37.55 & 80 \\
\hline \multicolumn{11}{|c|}{ Physical Characterization } \\
\hline Local & & Silt & \multicolumn{2}{|r|}{$\frac{\text { Fine Sand }}{\left({\left.\text { dag } \mathrm{kg}^{-1}\right)}\right.}$} & \multicolumn{3}{|c|}{ Coarse Sand } & \multicolumn{2}{|c|}{ Textural Class } & \\
\hline $\begin{array}{l}\text { Montes } \\
\text { Claros }\end{array}$ & 28.0 & \multicolumn{2}{|l|}{40.0} & 20.0 & \multicolumn{3}{|c|}{12.0} & \multicolumn{2}{|c|}{ Medium } & \\
\hline Januária & 6.0 & \multicolumn{2}{|l|}{8.0} & 51.40 & \multicolumn{3}{|c|}{34.6} & \multicolumn{2}{|c|}{ Sandy } & \\
\hline
\end{tabular}

* $\mathrm{OM}=$ organic matter, rem-P = remaining phosphorus.

Table 2. Minimum, average, and maximum temperatures, relative humidity and precipitation during the period the experiments were conducted, in the municipalities of Montes Claros and Januária, MG.

\begin{tabular}{|c|c|c|c|c|c|c|c|}
\hline \multirow{3}{*}{$\begin{array}{c}\text { Climatic } \\
\text { characteristics }\end{array}$} & \multicolumn{7}{|c|}{ Month } \\
\hline & May & June & July & August & September & October & $\overline{\text { November }}$ \\
\hline & \multicolumn{7}{|c|}{ Montes Claros } \\
\hline $\mathrm{T}^{\circ} \mathrm{C}$ Maximum & 29.3 & 29.0 & 28.8 & 29.9 & 35.3 & 35.5 & 35.2 \\
\hline $\mathrm{T}^{\circ} \mathrm{C}$ Average & 23.5 & 22.6 & 22.5 & 23.2 & 27.8 & 28.7 & 29.0 \\
\hline $\mathrm{T}^{\circ} \mathrm{C}$ Minimum & 17.7 & 16.3 & 16.1 & 16.5 & 20.3 & 21.8 & 22.9 \\
\hline Precipitation (mm) & 5.4 & 0.0 & 0.0 & 1.1 & 0.2 & 3.0 & 103.2 \\
\hline \multirow[t]{2}{*}{ Air humidity $(\%)$} & 62.9 & 55.2 & 54.5 & 48.1 & 38.5 & 41.0 & 52.7 \\
\hline & \multicolumn{7}{|c|}{ Januária } \\
\hline $\mathrm{T}^{\circ} \mathrm{C}$ Maximum & 25.8 & 25.5 & 25.5 & 26.3 & 30.6 & 31.4 & 31.0 \\
\hline $\mathrm{T}^{\circ} \mathrm{C}$ Average & 23.2 & 22.1 & 22.0 & 22.1 & 25.0 & 25.9 & 26.6 \\
\hline $\mathrm{T}^{\circ} \mathrm{C}$ Minimum & 20.5 & 18.8 & 18.4 & 17.9 & 19.4 & 20.4 & 22.1 \\
\hline Precipitation (mm) & 19.0 & 0.0 & 0.2 & 0.0 & 0.2 & 3.0 & 0.0 \\
\hline Air humidity (\%) & 61.1 & 51.8 & 49.6 & 42.7 & 33.0 & 35.0 & 47.4 \\
\hline
\end{tabular}

Hoeing was conducted weekly for weed control, until the closure of the area at 30 DAE. After the beginning of flowering, insecticide was applied three times. The first two times were with a systemic insecticide (neonicotinoid and pyrethroid), and the third with a contact insecticide (pyrethroid; the basis of deltamethrin [2.5\%]) for the control of caterpillars (Heliothis virescens), with intervals of 15 days between applications of insecticides.

Irrigation was suspended at 100 days after sowing, when the plants were coloring, indicating a change in stage of senescence, as recommended by Nascimento et al. (2016). The chickpeas were harvested 121 days after sowing.

The variables analyzed were the heights of the plants, yield, number of pods with one grain, and the number of pods with two grains. The data on the number of pods with one grain and the number of pods with two grains underwent a square root transformation $(\sqrt{x})$, although we present the original values. The data were subjected to analysis of variance (ANOVA) using joint analysis of the experiments, and averages were compared by Tukey test at $5 \%$ probability. The correlations between variables were analyzed by the method of Pearson at $5 \%$ probability. All data analysis was conducted with R software (v. 3.2.2).

\section{RESULTS AND DISCUSSION}

The number of pods (with one and two grains) and the yield of the chickpeas were affected by the interaction between time of sowing and location of the experiment $(p<0.05)$. The height of plants was affected only by the sowing season (Table 3). 
There are few records on the productive characteristics of the BRS Aleppo cultivar. The highest productivity was achieved when chickpeas were sown in May in Montes Claros - MG, exceeding $5.0 \mathrm{t} \mathrm{ha}^{-1}$ (Figure 1). For chickpea sown in June, there was no statistical difference between sites, with an average yield of $3.6 \mathrm{tha}^{-1}$. The biggest difference between sites was when chickpeas were sown in July, with a fairly drastic reduction in productivity in the municipality of Januária - MG. The highest productivity was achieved when chickpeas were sown in May in Montes Claros MG.

Table 3. Summary of the joint analysis of variance of the experiments, for variables of production of chickpeas in relation to times of sowing, in the municipalities of Montes Claros and Januária, Minas Gerais.

\begin{tabular}{cccccc}
\hline & \multicolumn{5}{c}{ QM } \\
\cline { 2 - 6 } $\mathrm{V}$ & $\mathrm{DF}$ & $\mathrm{HGT}$ & $\mathrm{NP} 1^{\mathrm{t}}$ & $\mathrm{NP} 2^{\mathrm{t}}$ & YLD \\
\hline Blocks/Exp & 12 & 30.0 & 1.09 & 0.2 & 0.5 \\
Time of sowing & 2 & $461.0^{*}$ & $20.2^{\mathrm{ns}}$ & $4.05^{\mathrm{ns}}$ & $8.6^{\mathrm{ns}}$ \\
Local & 1 & $1.7^{\mathrm{ns}}$ & $22.5^{\mathrm{ns}}$ & $1.3^{\mathrm{ns}}$ & $26.7^{\mathrm{ns}}$ \\
Time x Local & 2 & $15.8^{\mathrm{ns}}$ & $14.4^{* *}$ & $4.6^{* *}$ & $4.0^{* *}$ \\
Residue & 10 & 54.2 & 0.6 & 0.2 & 0.4 \\
\hline CV $(\%)$ & 12.3 & 11.5 & 15.4 & 18.8 \\
\hline
\end{tabular}

*, **Probability of 5 and $1 \%$, respectively, for the F-test.

$(\mathrm{V}=$ source of variation, $\mathrm{DF}=$ degrees of freedom), for the variables: plant height (HGT), number of pods

with one grain (NP1), number of pods with two grains (NP2), yield (YLD).

t - transformed values.

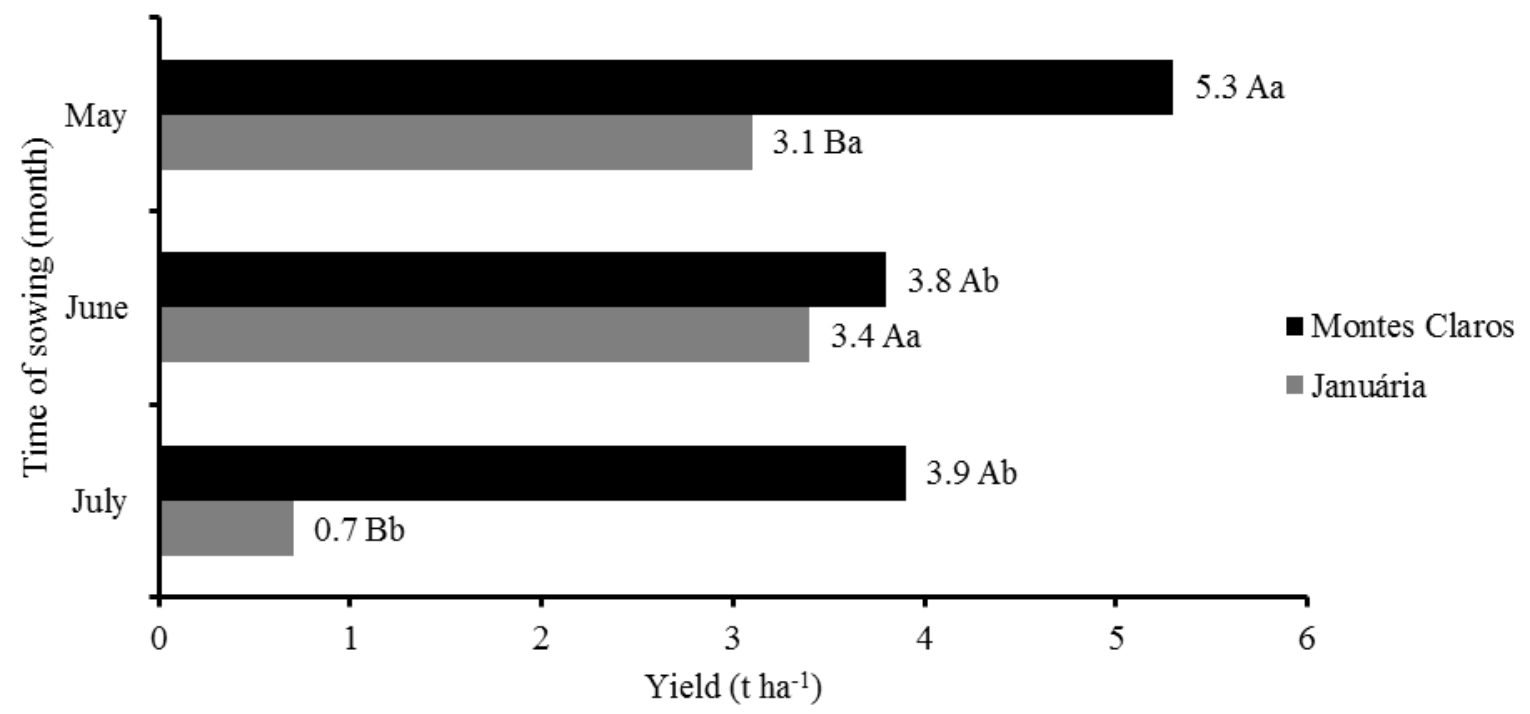

*Averages followed by the same uppercase letter in the columns of the sites do not differ significantly, as evaluated by F-tests, and averages followed by lowercase letters in the columns of the sites do not differ significantly, as evaluated by Tukey test, at $5 \%$ probability.

Figure 1. The yield of chickpeas sown at different sowing times in the municipalities of Montes Claros and Januária, Minas Gerais.

In trials conducted during four years in areas of Cerrado of Distrito Federal and Goiás, Nascimento et al. (2014) observed yields of the BRS Aleppo cultivar ranged from $2.51 \mathrm{tha}^{-1}$ to $3.52 \mathrm{t} \mathrm{ha}^{-}$ 1 . In the same period, the Cicero cultivar produced yields from $0.44 \mathrm{t} \mathrm{ha}^{-1}$ to $1.27 \mathrm{t} \mathrm{ha}^{-1}$.

Under conditions similar to those in the present study, Hoskem et al. (2017) tested the Cicero cultivar at three different sowing times (May 22 ${ }^{\text {nd }}$, June $20^{\text {th }}$, and July $26^{\text {th }}$ ), and reported yields averaging $2.72 \mathrm{t} \mathrm{ha}{ }^{-1}$, with the best result obtained when chickpeas were sown in the month of June, with yields close to $3 \mathrm{t} \mathrm{ha}^{-1}$.

Evaluating the chickpea cultivars in Coimbra, a municipality of Zona da Mata-MG, at an altitude of $800 \mathrm{~m}$, in 1993 and 1994, Braga, Vieira and Vieira (1997), reported yields from 1.58 to $1.62 \mathrm{t}$ ha ${ }^{-1}$ with the IAC Morocco cultivar, yields from 2.04 to $2.35 \mathrm{t}$ ha ${ }^{-1}$ with the ICCV-3 (Leopoldina) cultivar, and yields from 1.03 to $1.46 \mathrm{t}$ ha ${ }^{-1}$ with the Cicero cultivar. In a study by Vieira, Rezende and Castro (1999), in the Zona da Mata and in the North of Minas, the IAC Moroco cultivar, grown in the municipality of Coimbra (micro-region of 
Viçosa-MG), provided a yield of $1.79 \mathrm{t} \mathrm{ha}^{-1}$. In Leopoldina-MG and Janaúba-MG, the Leopoldina and IAC Morocco cultivars reached yields greater than $2 \mathrm{t} \mathrm{ha}^{-1}$ and $3 \mathrm{t} \mathrm{ha}^{-1}$, respectively. The Cicero cultivar did not produce yields greater than $1.80 \mathrm{tha}^{-1}$.

A study by Artiaga et al. (2015), using 15 chickpea genotypes in non-irrigated land cultivation in the Midwest region of Brazil during three seasons of planting, reported yields up to $1.34 \mathrm{t} \mathrm{ha}^{-1}$. For the IAC Morocco and Cicero cultivars, the maximum yield was $0.34 \mathrm{t} \mathrm{ha}^{-1}$ when soybeans were sown the month of March, and $0.62 \mathrm{tha}^{-1}$ when chickpeas were sown in the month of January, respectively.

Regarding the height of plants, greater values were found in chickpeas sown in May, and heights were reduced in the chickpeas sown in July (Table 4). According to NASCIMENTO et al. (2014), the height of the plants of the cultivar BRS Aleppo is approximately $66 \mathrm{~cm}$, which is similar to the values obtained in this study for the chickpeas sown in May and June.

Table 4. Plant height, number of pods with one grain, and number of pods with two grains of chickpeas in relation to sowing times in the municipalities of Montes Claros and Januária, Minas Gerais.

\begin{tabular}{lccccc}
\hline \multirow{2}{*}{$\begin{array}{l}\text { Time of } \\
\text { sowing }\end{array}$} & \multirow{2}{*}{$\begin{array}{c}\text { Height } \\
(\mathrm{cm})\end{array}$} & & \multicolumn{4}{c}{ Locals } \\
\cline { 3 - 6 } & & Montes Claros & Jumber of pods with 1 grain (plant) & Number of pods with 2 grains (plant) \\
\hline May 12 & $64.7 \mathrm{a}$ & $9.7^{*}\left(85.9^{* *}\right) \mathrm{Aa}$ & $6.9(41.9) \mathrm{Ba}$ & $3.0\left(6.4^{* *}\right) \mathrm{Ba}$ & $3.9(11.6) \mathrm{Aa}$ \\
June 23 & $61.2 \mathrm{ab}$ & $5.4(25) \mathrm{Bc}$ & $7.2(44.8) \mathrm{Aa}$ & $1.6(1.4) \mathrm{Bb}$ & $2.9(6.5) \mathrm{Ab}$ \\
July 22 & $51.0 \mathrm{~b}$ & $7.5(49.3) \mathrm{Ab}$ & $3.7(10.5) \mathrm{Bb}$ & $3.04(6.6) \mathrm{Aa}$ & $1.9(2.1) \mathrm{Bc}$ \\
\hline $\mathrm{CV}(\%)$ & 12.3 & \multicolumn{3}{c}{11.5} \\
\hline
\end{tabular}

Averages followed by the same uppercase letter in a line do not differ significantly, based on analysis using the F-test, and averages followed by the same lowercase letters in a column do not differ significantly based on analysis using the Turkey test at $5 \%$ probability.

*Data was transformed by $(\sqrt{x}+0.5) * *$ Non-transformed data.

Artiaga et al. (2015), assessed chickpea genotypes sown in non-irrigated land in the Midwest of Brazil from January to July, and found heights for the Cicero cultivar ranging from 33 to $57 \mathrm{~cm}$, and heights for the IAC Morocco cultivar ranging from 45 to $63 \mathrm{~cm}$. Hoskem et al. (2017), using the Cicero cultivar, found the highest values for plant height $(52 \mathrm{~cm})$ in the municipality of Montes Claros-MG when chickpeas were sown in May.

Considering cultures with indeterminate growth habits (GAUR et al., 2010), plants of greater height, in general, result in higher production, taking into consideration their normal development. This is related to the cycle of cultivars. For example, the Cicero cultivar has a cycle of approximately 110 days, while that of the BRS Aleppo cultivar is 120 days.

In addition, temperature and air humidity affect production. Temperatures below $10{ }^{\circ} \mathrm{C}$ and above $30{ }^{\circ} \mathrm{C}$ are detrimental to the development of the chickpea cultivars, especially in the reproductive phase, and may cause abortion of flower buds and affect the formation of pods (NASCIMENTO et al., 2016). Under conditions of temperatures above the optimum for the cultivar, its cycle is shortened, resulting on premature senescence, and the production and viability of pollen grains are reduced (KUMAR et al., 2013), which negatively affects the production of the cultivar (DEVARSIVATHAM et al., 2012).

The number of pods with one grain (Table 4) was higher when chickpeas were sown in May in Montes Claros, and the number of pods with two grains (Table 4) was higher when chickpeas were sown in May in Januária.

During the experimental period, maximum temperatures over $30^{\circ} \mathrm{C}$ were recorded from the month of September onwards in both locations, which resulted in the reduction of the number of grains (Table 2). The plants that were sown in May were at the end of the cycle, and, therefore, the high temperatures did not harm their development.

The yield and the number of pods with one grain were highly positively correlated (Table 5). The pods that produce just one grain, found in greater numbers, feature larger grain weight, compared to grains produced in greater numbers per pod. There was a weak correlation $(\mathrm{r}=0.39)$ between productivity and plant height. Artiaga et al. (2015) and Biabani et al. (2011) found a positive correlation between such variables, reporting values of $r=0.61$ and $r=0.78$. Samad, Sarker and Deb (2014) observed a negative correlation between plant height at maximum flowering and grain number per plant.

In this study, it can be inferred that the tallest plants had a higher vegetative development, without producing more grains.

The number of pods with one grain was also correlated with the number of pods with two grains, indicating that when production increases, there is also a greater number of pods with two grains. 
Table 5. Simple Pearson correlation between the variables evaluated regarding the production of chickpeas of the BRS Aleppo cultivar at different sowing times in the municipalities of Montes Claros and Januária, Minas Gerais.

\begin{tabular}{lccc}
\hline & HGT & NP1 & NP2 \\
\hline YLD & $0.39^{*}$ & $0.92^{* *}$ & $0.34^{\mathrm{ns}}$ \\
HGT & & $0.42^{*}$ & $0.22^{\mathrm{ns}}$ \\
NP1 & & & $0.37^{*}$ \\
\hline
\end{tabular}

$* *=1 \%$ probability, $*=5 \%$ probability, Pearson's correlation.

YLD = yield; HGT = height of plants; NP1 = number of pods with one grain (plant); NP2 = number of pods with two grains (plant).

\section{CONCLUSION}

The best time for the sowing of chickpeas in the municipality of Montes Claros - MG was in May, with a yield of $5.3 \mathrm{t} \mathrm{ha}^{-1}$. In the municipality of Januária - MG, the best times for sowing chickpeas were the months of May and June, with a yield exceeding $3 \mathrm{tha}^{-1}$.

\section{REFERENCES}

ABATE, T.; ORR, A. Research, and development for tropical legumes: Towards a knowledge-based strategy. Journal of SAT Agricultural Research, Patancheru, v. 10, n. 1, p. 1-12, 2012.

ALI, M. H. Response of Chickpea Varieties to Different Irrigation Regimes. Asian Journal of Advances in Agricultural Research, Bangladesh, v. 2, n. 4, p. 1-7, 2017.

ARTIAGA, O. P. et al. Evaluation of chickpea genotypes under rain-fed conditions in the Brazilian 'Cerrado' region. Revista Brasileira de CiênciasAgrárias, Recife, v. 10, n. 1, p. 102-109, 2015.

BIABANI, A. et al. Correlation, and relationships between seed yield and other characteristics in chickpea (Cicer arietinum L.) cultivars under deterioration. African Journal of Agricultural Research, Nairobi, v. 6, n. 6, p. 1359-1362, 2011.

BRAGA, N. R.; VIEIRA, C.; VIEIRA, R. F. Comportamento de cultivares de grão-de-bico (Cicer arietinum L.) na microrregião de Viçosa, Minas Gerais. Revista Ceres, Viçosa, v. 44, n. 255, p. 577591, 1997.

BRASIL. INSTITUTO NACIONAL DE METEOROLOGIA - INMET. Banco de Dados Meteorológicos para Ensino e Pesquisa BDMEP, 2016. Disponível em: <http:// www.inmet.gov.br/portal/index.php?r=bdmep/ bdmep>. Acesso em: 8 Abr. 2016.

DEVARSIVATHAM, V. et al. Effect of high temperature on the reproductive development of chickpea genotypes under controlled environments.
Functional Plant Biology, Melbourne, v. 39, n. 1, p. 109-118, 2012.

FOOD AND AGRICULTURE ORGANIZATION OF THE UNITED NATIONS - FAO. Food and agriculture data. In: FAOSTAT. Rome, Italy, 2018. Disponível em: <http://faostat.fao.org/site/291/ default.aspx>. Acesso em: 20 Abr. 2018.

GAUR, P. M. et al. Chickpea seed production manual. International Crops Research Institute for the Semi-Arid Tropics, Andhra Pradesh, India, 28 p., 2010.

GUNES, A. et al. Effect of Drought Stress Implemented at Pre- or Post-Anthesis Stage on Some Physiological Parameters as Screening Criteria in Chickpea Cultivars. Russian Journal of Plant Physiology, Moscow, v. 55, n. 1, p. 59-67, 2008.

HOSKEM, B. C. S. et al. Productivity and quality of chickpea seeds in Northern Minas Gerais, Brazil. Revista Brasileira de Ciencias Agrárias, Recife, v. 12, n. 1, p. 261-268, 2017.

JUKANTI, A. et al. Nutritional quality and health benefits of chickpea (Cicer arietinum L.): A review. British Journal of Nutrition, Cambridge, v. 108, n. 1, p. 11-26, 2012.

KHAMSSI, N. N. et al. Evaluation of grain filling rate, effective grain filling period and resistance indices under acclimation to gradual water deficit stress in chickpea cultivars. Australian Journal of Crop Science, Brisbane, v. 5, n. 6, p. 1044-1049, 2011.

KUMAR, S. et al. Effect of varying high temperatures during reproductive growth on reproductive function, oxidative stress and seed yield in chickpea genotypes differing in heat sensitivity. Archives of Agronomy and Soil Science, London, v. 59, n. 6, p. 823-843, 2013.

MAFAKHERI, A. et al. Effect of drought stress on yield, proline and chlorophyll contents in three chickpea cultivars. Australian Journal of Crop Science, Brisbane, v. 4, n. 8, p. 580-585, 2010.

NASCIMENTO, W. M. et al. Grão-de-bico. In: 
NASCIMENTO, W. M. (Ed.). Hortaliças leguminosas. 1. ed. Brasília, DF: Embrapa Informação Tecnológica, 2016. v. 1, cap. 3, p. 89118.

NASCIMENTO, W. M. et al. BRS Aleppo: chickpeas. Greater tolerance to soil fungi. 1 . ed. Brasília, DF: Embrapa Hortaliças, 2014. 2 p.

RAO, P. P. et al. Chickpea and Pigeon pea Economies in Asia: Facts, Trends, and Outlook. International Crops Research Institute for the SemiArid Tropics, Patancheru, Andhra Pradesh, India, p. 1-76, 2010.

SAMAD, M. A.; SARKER, N.; DEB, A. C. Study on relationship and selection index in chickpea. Tropical Plant Research, Kanpur, v. 1, n. 3, p. 27 35, 2014.

VARSHNEY, R. K. et al. Draft genome sequence of chickpea (Cicer arietinum) provides a resource for trait improvement. Nature Biotechnology, Andhra Pradesh, v. 31, n. 3, p. 240-248, 2013 a.

VARSHNEY, R. K. et al. Genetic dissection of drought tolerance in chickpea (Cicer arietinum L.). Theoretical and Applied Genetics, Andhra Pradesh, v. 127, n. 11, p. 445-462, 2013 b.

VIEIRA, R. F.; RESENDE, M. A. V.; CASTRO, M. C. S. Behaviour of chickpea cultivars in "Zona da Mata" and northern Minas Gerais State, Brazil. Horticultura Brasileira, Brasília, v. 17, n. 2, p. 166$170,1999$. 